\section{Birlesik Dünya Arastrma Cypriot Journal of Educational \\ Sciences}

Volume 15, Issue 5, (2020) 1295 - 1306

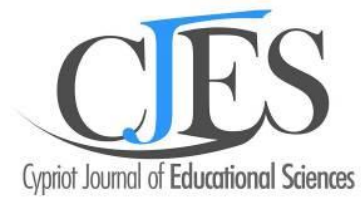

www.cjes.eu

\title{
Blended learning in improving students' critical thinking and communication skills at University
}

\author{
Hasanah Hasanah ${ }^{\text {* }}$, Universitas Negeri Makassar, A.P. Pettarani Street, Makassar, 90222, Indonesia \\ https://orcid.org/0000-0002-6209-9451 \\ Muh. Nasir Malik ${ }^{\text {b }}$, Universitas Negeri Makassar, A.P. Pettarani Street, Makassar, 90222, Indonesia
}

\section{Suggested Citation:}

Hasanah, H. \& Malik, M. N. (2020). Blended learning in improving students' critical thinking and communication skills at University. Cypriot Journal of Educational Science. 15(5), 1295 - 1306. https://doi.org/10.18844/cjes.v15i5.5168

Received from August 01 2020; revised from 25 August 2020; accepted from October 26, 2020. (C2020 Birlesik Dunya Yenilik Arastirma ve Yayincilik Merkezi. All rights reserved.

\begin{abstract}
This study investigates the effectiveness of the blended learning model in improving critical thinking and communication skills of students at university. This is a quasi-experimental study with a non-equivalent control group design involving one experimental group and one control group. The research population comprised students sitting in the Entrepreneurship class at the Department of Electronic Engineering Education, who were selected purposively. The data were about critical thinking skills that were gathered using a test, while the data about communication skills were obtained through observations. The data were analysed using a paired sample $t$-test and an independent sample $t$-test. The findings show that: (1) the implementation of the blended learning model effectively increases the critical thinking skills; (2) the use of the blended learning model effectively improves students' communication skills and (3) according to the independent sample $t$-test, students' critical thinking skills and communication skills in the experimental class had a significant difference from those in the control class.
\end{abstract}

Keywords: Blended learning model, critical thinking skills, communication skills.

\footnotetext{
* ADDRESS FOR CORRESPONDENCE: Hasanah, Hasanah, Universitas Negeri Makassar, A.P. Pettarani Street, Makassar, 90222, Indonesia E-mail address: hasanah@unm.ac.id / Tel.: +62-85726427079
} 


\section{Introduction}

The development of the 21st century is marked by the use of information and communication technologies in many life sectors, including learning. The spread of coronavirus disease 2019 (COVID19) in Indonesia in the middle of March 2020 requires an adjustment in the learning system. Initially, students had to go to the campus to join face-to-face learning with the lecturers. However, since the large-scale social distance programme was applied, face-to-face learning was limited. Some countries have still implemented education process during the emergency period of COVID-19, stating that the learning activities have to be conducted online to prevent the spread of COVID-19. However, it should be considered that the delivery of character education online is less effective since it needs direct interaction between educators and learners. Therefore, one of the learning alternatives to be applied during the COVID-19 pandemic era is blended learning.

Blended learning is one of the learning models that can be implemented using ICT-based media. It combines classroom learning and online learning. However, in the pandemic era, the online methods that can be utilised are both synchronous and asynchronous. The three important components of blended learning are online learning, face-to-face learning and self-study. Learners can study without being limited by space and time. According to Dwiyogo (2018a; 2018b), blended learning's main goal is to stimulate learners to maximise the face-to-face learning with the support of their knowledge about e-learning so that the next step can be conducted offline and online. Furthermore, the studies of Yu et al. (2015) and Tsai and Tang (2017) found that the implementation of blended learning shows a positive impact on problem-solving skills and the improvement is more significant compared to traditional learning, and it positively influences the learning achievement. A similar finding by Wahyuni et al. (2019) explained that the blended learning model influences students' learning results.

According to Blau et al. (2020), the development of technology for education is to boost not only the cognitive aspects but also affective and attitude components. Therefore, we should develop a learning model that can cover more comprehensive aspects. Limitation of time and access to the learning material has become the main barrier in improving the quality of students. By using the blended learning model that combines online and face-to-face learning, the learning activities can be more effective and the output will be better. Blended learning allows lecturers to deliver a more comprehensive learning experience to students. It does not only offer wider experiences to students but it also provides many other benefits like supporting students to access the learning materials, boosting the learning quality and reducing the learning cost (Blau et al., 2020).

Some studies show that the implementation of blended learning improves the employability skills of students. The study conducted by Lane (2016) found that the application of blended learning that combines traditional and online learning can increase students' employability skills. According to Hart (2019), the employability skills are related to one's ability to work under various circumstances, think critically and communicate effectively; therefore, they are powerful and spiritful to keep studying and working. Employability skills are considered to be very important because one of the characteristics of the current job demand is that it requires initiative, flexibility and ability to handle various kinds of tasks. Lane (2016) found that the implementation of the blended learning model can increase students' employability skills, wherein the application of the method in teaching can boost students' critical thinking skills and trigger them to communicate more effectively.

Several studies have shown that e-learning media can improve students' critical thinking skills. Critical thinking skills as one of the 21st century skills must be one of the non-cognitive abilities that are prioritized in the learning process (Ristanto et al., 2020). According to Sadri et al., (2019) and Smith et al., (2019) the ability to think critically makes students reanalyze, identify, evaluate, consider, re- 
develop all the ideas and all the assumptions they get so that in the end it will lead to a decision or a conclusion that is considered the best and can be done. The 21st century skill that students must have in addition to critical thinking skills is the ability to communicate. Good communication skills are invaluable skills in the world of work and everyday life.

Communication skills include skills in conveying thoughts clearly and persuasively orally and in writing, the ability to convey opinions in clear sentences, convey clear commands, and be able to motivate others through good speaking skills. There are several indicators of critical thinking skills: (1) formulating problems, namely a person's skills in analyzing every problem in a course, (2) providing arguments accompanied by scientific evidence from existing literature with good articulation, (3) implementing evaluation which is accompanied by facts, principles or existing guidelines and (4) draws conclusions, namely determining solutions to the problems that occur (Cahyani \& Azizah, 2019; Hunaepi et al., 2020). As for communication skills, according to Kyaw et al. (2019) and Sagala et al. (2019) communication skills can be seen from several aspects, namely 1) oral communication, 2) written communication, 3) listening skill and 4) communication content.

According to the previous mentioned studies, it can be concluded that there are many previos studies conducting blended learning model which is related to the critical thinking skill and communication skill of students. However the studies were conducted both variables partially, not simultaneously. Moreover, lack of studies conducting these variables in the vocational school or vocational department has been one of the fact showing the importance of conducting this study in the vocational department in the university. Therefore, this study investigated the effectiveness of the implementation of the blended learning model to increase students' critical thinking and communication skills at university.

\section{Research Method}

This study employed a quasi-experimental design and selected the subjects randomly. The non-equivalent control group design was applied and involved experimental and control groups. This research was carried out in the Department of Electronic Engineering Education. The research population comprised students who studied Entrepreneurship in the department.

Table 1. The number of research samples

\begin{tabular}{cccc}
\hline Subject & Experimental class & Control class & Total \\
\hline Entrepreneurship & 47 & 45 & 92 \\
\hline
\end{tabular}

The samples were selected using the purposive sampling technique to consider particular conditions of each sample. They were grouped into two classes: class $A$, an experimental group consisting of 47 students, and class B, a control group consisting of 45 students. This study used the Critical Thinking Skills Scale (CTSS) developed by Demir (2006). There are six dimensions of critical thinking measured by the CTSS (interpretation, analysis, inference, explanation, evaluation and selfregulation). This scale was used by many previous researchers who conducted classes on critical thinking skills (Dilekli, 2017; Erdogan, 2020; Kavenuke, Kinyota \& Kayombo, 2020). It implies that this scale is considered suitable to measure the critical thinking skills of students.

To measure the communication skills variable, the Communication Competence Scale (CCS) was used (adapted from Topluer, 2008). This scale consists of three dimensions, namely empathy (17 items), social relaxation ( 7 items) and support ( 7 items). This scale was used by many previous researchers who conducted classes on communication skill for students (Rubin, Palmgreen \& Sypher, 2020; Ustuner \& Kis, 2014). The scales were pre-tested by involving 20 students, and the result shows 
that Cronbach's alpha was 0.75. It implies that the scales have a good level of reliability. In addition, the corrected item-total correlation value for each item was higher than the $R$-table $(0.4683)$. It implies that all items in this scale have met the validity standard.

All data were then analysed using $t$-tests, which in this case were paired sample $t$-test and independent sample $t$-test. Before that, we carried out classical assumption tests consisting of normality test using the Shapiro-Wilk and homogeneity tests, with the Levene test as the requirement before carrying out the analyses. The paired sample $t$-test was used to measure the effectiveness of the blended learning model, while the independent sample $t$-test was used to compare the critical thinking and communication skills between students in the experimental and control groups

\section{Results and Discussion}

Inferential statistical analysis was carried out after completing the requirement of the classical assumption tests, which consist of the normality test and the homogeneity test. The results of the normality test applied to data about students' critical thinking skills in both experimental and control groups are presented in Table 2.

Table 2. Normality data of critical thinking skills

\begin{tabular}{llrrr}
\hline & & Statistic & Df & \multicolumn{1}{c}{ Sig. } \\
\hline Pre-test & Experimental class & 0.962 & 47 & 0.129 \\
\cline { 2 - 5 } & Control class & 0.985 & 45 & 0.812 \\
\hline \multirow{2}{*}{ Post-test } & Experimental class & 0.973 & 47 & 0.331 \\
\cline { 2 - 5 } & Control class & 0.974 & 45 & 0.393 \\
\hline
\end{tabular}

Table 2 shows that the sig. values of the critical thinking skills of the experimental group in both the pre-test and post-test were greater than 0.05 . Therefore, they can be assumed to have a normal distribution. Furthermore, the sig. values of critical thinking skills of students in the control group based on the pre-test and post-test were also greater than 0.05 , meaning that the data were also normally distributed. The results of normality tests carried out on the data about students' communication skills in both experimental and control groups are presented in Table 3.

Table 3. The normality data of communication skills

\begin{tabular}{llrrr}
\hline & & Statistic & Df & \multicolumn{1}{c}{ Sig. } \\
\hline Pre-test & Experimental class & 0.983 & 47 & 0.709 \\
\cline { 2 - 5 } & Control class & 0.972 & 45 & 0.340 \\
\hline \multirow{2}{*}{ Post-test } & Experimental class & 0.965 & 47 & 0.175 \\
\cline { 2 - 5 } & Control class & 0.954 & 45 & 0.071 \\
\hline
\end{tabular}

Table 3 shows that the sig. values of communication skills in the experimental group in both pre-test and post-test were greater than 0.05; thus, it can be assumed that the data of the experimental group were normally distributed. Then, the sig. values of students' communication skills in the control group based on pre-test and post-test were greater than 0.05 , meaning that the data were normally distributed. The next assumption test data to be presented is the homogeneity test. Table 4 shows the results of the homogeneity test on the data about critical thinking skills. 
Table 4. The homogeneity of data about critical thinking skills

\begin{tabular}{llrrrr}
\hline & & Levene statistic & df1 & df2 & Sig. \\
\hline Pre-test & Based on Mean & 0.497 & 1 & 90 & 0.483 \\
Post-test & Based on Mean & 1.344 & 1 & 90 & 0.249 \\
\hline
\end{tabular}

Based on Table 4, it can be seen that the sig. values of the pre-test and post-test were 0.483 and 0.249 , respectively, and both of them are greater than 0.05 . It indicates that the data were homogeneous or they had similar variants. The results of the homogeneity test for data about communication skills are presented in Table 5.

Tabel 5. The homogeneity of data about communication skills

\begin{tabular}{|c|c|c|c|c|c|}
\hline & & Levene statistic & df1 & df2 & Sig. \\
\hline Pre-test & Based on mean & 1,889 & 1 & 90 & 0.173 \\
\hline Post-test & Based on mean & 0.018 & 1 & 90 & 0.895 \\
\hline
\end{tabular}

Table 5 shows that the sig. value of the pre-test was 0.173 , while that of the post-test was 0.895 , and both were greater than 0.05 . This shows that the data were homogeneous or the variations of data about communication skills have the same variants. After meeting the criteria of the classical assumption test, we carried out a paired sample $t$-test to measure the effectiveness of the blended learning model in the critical thinking and communication skills, and $t$-test to identify the difference in critical thinking and communication skills between students in the experimental class and students taught with conventional learning.

\section{a. The effectiveness of the blended learning model on students' critical thinking and communication skills}

The results of the descriptive statistical analysis show that there was an improvement in students' critical thinking skills after the implementation of blended learning. This is indicated by the mean scores before and after the implementation of the teaching method presented in Table 6 .

Table 6. Descriptive analysis of the critical thinking skills of a student in the experimental group

\begin{tabular}{llllcc}
\hline & Mean & $N$ & $\begin{array}{c}\text { Std. } \\
\text { deviation }\end{array}$ & $\begin{array}{c}\text { Std. error } \\
\text { mean }\end{array}$ \\
\hline Pair 1 & Pre-test & 56.77 & 47 & 7.786 & 1.136 \\
& Post-test & 81.40 & 47 & 7.282 & 1.062 \\
\hline
\end{tabular}

Table 6 shows that the average post-test score was 81.40, which is higher than the average pre-test score which was 56.77. This implies that there was an increase in the critical thinking skills of students in the experimental group. However, to identify the significance and effectiveness of the blended learning model, we carried out a paired sample $t$-test as shown in Table 7.

Table 7 shows that the sig. value was lesser than 0.05 , and the $t$-count was greater than the $t$ table. Thus, the implementation of the blended learning model was effective in improving students' critical thinking skills. In terms of the students' communication skills, the result of the descriptive statistical analysis shows that after the implementation of the blended learning model, students in the experimental group had a better ability to communicate than before. The results are presented in Table 8. 
Table 7. Data of paired sample $t$-test results of critical thinking skills

\begin{tabular}{|c|c|c|c|c|c|c|c|}
\hline & \multicolumn{5}{|c|}{ Paired differences } & \multirow[b]{2}{*}{$\begin{array}{l}\text { Sig. (2- } \\
\text { tailed) }\end{array}$} \\
\hline & & Mean & $\begin{array}{c}\text { Std. } \\
\text { deviation }\end{array}$ & $\begin{array}{l}\text { Std. error } \\
\text { mean }\end{array}$ & $t$ & $d f$ & \\
\hline $\begin{array}{l}\text { Pair } \\
1\end{array}$ & $\begin{array}{l}\text { Post-test- } \\
\text { Pre-test }\end{array}$ & 24.638 & 5.597 & 0.816 & 30.181 & 46 & 0.000 \\
\hline
\end{tabular}

Table 8. Communication skills of the experimental group

\begin{tabular}{llcccc}
\hline & Mean & $N$ & $\begin{array}{c}\text { Std. } \\
\text { deviation }\end{array}$ & $\begin{array}{c}\text { Std. error } \\
\text { mean }\end{array}$ \\
\hline Pair 1 & $\begin{array}{l}\text { Pre- } \\
\text { test }\end{array}$ & 57.17 & 47 & 6.044 & 0.882 \\
\cline { 2 - 6 } & $\begin{array}{l}\text { Post- } \\
\text { test }\end{array}$ & 68.96 & 47 & 5.065 & 0.739 \\
\hline
\end{tabular}

It can be seen from Table 8 that the mean post-test score was 68.96 , which is higher than the mean pre-test score which was only 57.17. This implies that there was an improvement in students' communication skills in the experimental group. Yet, to identify the significance of the improvement of the communication skills and the effectiveness of the blended learning model, we conducted a paired sample $t$-test as shown in Table 9.

Table 9. Data of paired sample $t$-test results about communication skills

\begin{tabular}{|c|c|c|c|c|c|c|c|}
\hline & \multicolumn{5}{|c|}{ Paired differences } & \multirow[b]{2}{*}{$\begin{array}{l}\text { Sig. }(2 \\
\text { tailed) }\end{array}$} \\
\hline & & Mean & $\begin{array}{c}\text { Std. } \\
\text { deviation }\end{array}$ & $\begin{array}{l}\text { Std. error } \\
\text { mean }\end{array}$ & $t$ & $d f$ & \\
\hline $\begin{array}{l}\text { Pair } \\
1\end{array}$ & $\begin{array}{l}\text { Post-test- } \\
\text { Pre-test }\end{array}$ & 11.78 & 5.497 & 0.802 & 14.701 & 46 & 0.000 \\
\hline
\end{tabular}

The results of the paired sample $t$-test on data about students' critical thinking skills and communication skills indicate that the blended learning model is effective in boosting those skills.

b. The difference in critical thinking and communication skills between students in the experimental and control groups

There was a difference in students' critical skills, as students taught without and with the blended learning method obtained standard deviations of 71.69 and 81.40 , respectively. The results of inferential statistical analysis, which in this case was the paired sample $t$-test, strengthen the descriptive statistical analysis, as presented in Table 10.

Based on Table 10, the sig. values lower than 0.05 and the $t$-count higher than the $t$-table show that there is a significant difference between the critical thinking skills of the experimental and 
control groups. Thus, students taught with the blended learning model had better critical thinking skills compared to students taught with the conventional method. Besides that, it can be seen that the initial critical thinking skills obtained a mean difference of -8.612 , which implies that the value obtained by the experimental group was lower than the control group, while the critical thinking skills based on the post-test showed a mean difference of 9.715, which implies that the students in the experimental group showed better critical thinking skills compared to the control group students at the end of the research

Table 10. Data of independent sample $t$-test results about critical thinking skills

\begin{tabular}{|c|c|c|c|c|c|c|c|c|}
\hline & & \multicolumn{7}{|c|}{$t$-test for equality of means } \\
\hline & & \multirow[t]{2}{*}{$t$} & \multirow[t]{2}{*}{ df } & \multirow[t]{2}{*}{$\begin{array}{l}\text { Sig. (2- } \\
\text { tailed) }\end{array}$} & \multirow[t]{2}{*}{$\begin{array}{c}\text { Mean } \\
\text { difference }\end{array}$} & \multirow[t]{2}{*}{$\begin{array}{l}\text { Std. error } \\
\text { difference }\end{array}$} & \multicolumn{2}{|c|}{$\begin{array}{c}95 \% \text { confidence } \\
\text { interval of the } \\
\text { difference }\end{array}$} \\
\hline & & & & & & & Lower & Upper \\
\hline $\begin{array}{l}\text { Pre- } \\
\text { test }\end{array}$ & $\begin{array}{l}\text { Equal } \\
\text { variances } \\
\text { assumed }\end{array}$ & -5.469 & 90 & 0.000 & -8.612 & 1.575 & -11.740 & -5.483 \\
\hline $\begin{array}{l}\text { Post- } \\
\text { test }\end{array}$ & $\begin{array}{l}\text { Equal } \\
\text { variances } \\
\text { assumed }\end{array}$ & 6.807 & 90 & 0.000 & 9.715 & 1.427 & 6.880 & 12.551 \\
\hline
\end{tabular}

Furthermore, the independent sample $t$-test was carried out to evaluate whether there is a significant difference in their communication skills. Table 11 shows that the sig. value they obtained was lower than 0.05 and the $t$-count was higher than the $t$-table; so, it can be assumed that students following the blended learning had better communication skills compared to their peers treated with conventional learning. Besides that, it can be seen that the prior communication skills obtained a mean difference of -3.630 , implying that the score of the experimental group was lower than the control group, while after the two different learning models were applied, the mean difference was 2.269 , which implies that the communication skills of the experimental group turned out to be higher than that of the control group.

Table 11. Results of the independent sample $t$-test on data about communication skills

\begin{tabular}{|c|c|c|c|c|c|c|c|c|}
\hline & & \multicolumn{7}{|c|}{$t$-test for equality of means } \\
\hline & & \multirow[t]{2}{*}{$t$} & \multirow[t]{2}{*}{$\mathrm{df}$} & \multirow[t]{2}{*}{$\begin{array}{l}\text { Sig. (2- } \\
\text { tailed) }\end{array}$} & \multirow[t]{2}{*}{$\begin{array}{c}\text { Mean } \\
\text { difference }\end{array}$} & \multirow[t]{2}{*}{$\begin{array}{l}\text { Std. error } \\
\text { difference }\end{array}$} & \multicolumn{2}{|c|}{$\begin{array}{l}\text { 95\% confidence } \\
\text { interval of the } \\
\text { difference }\end{array}$} \\
\hline & & & & & & & Lower & Upper \\
\hline $\begin{array}{l}\text { Pre- } \\
\text { test }\end{array}$ & $\begin{array}{l}\text { Equal } \\
\text { variances } \\
\text { assumed }\end{array}$ & -2.63 & 90 & 0.010 & -3.630 & 1.380 & -6.371 & -0.888 \\
\hline $\begin{array}{l}\text { Post- } \\
\text { test }\end{array}$ & $\begin{array}{l}\text { Equal } \\
\text { variances } \\
\text { assumed }\end{array}$ & 2.180 & 90 & 0.032 & 2.269 & 1.041 & 0.201 & 4.336 \\
\hline
\end{tabular}


Based on the results of the independent sample $t$-test carried out on students' critical thinking skills and communication skills, students experimented with the blended learning model had better critical thinking skills and communication skills compared to students in the control group who were taught with a conventional method.

\section{c. Discussion}

The critical thinking skills of the experimental group after being taught with the blended learning model experienced an increase and had a more positive difference compared to the control group treated with traditional or conventional learning. The blended learning model was implemented synchronously or based on problems and collaboratively asynchronously and independently. 'Synchronous', in this case, means that the method applies the concept of problem-based learning as a model that provides problem orientation to students so that activities in the classroom can stimulate students to actively play roles. Besides that, the benefit of asynchronous collaborative learning is that it allows students to interact with each other and to share their knowledge about a subject so that they can get a basic knowledge to be discussed further in the classroom.

The integration of problem-based and face-to-face learning (live event) online also assists students to improve their ability to interpret information and make a conclusion based on the analysis they carry out, and to categorise or to classify information they obtain based on their needs. Due to the improvement of their critical thinking skills, students in the experimental group show their curiosity and concern on information obtained from the classroom learning, in both discussion activities and individual and group question and answer sessions. As a consequence, they were more flexible with classroom learning and e-learning, which are beneficial for their career in the future. Students can intensively communicate with lecturers about learning materials and can discuss them with their friends. It is important to allow students to maximise their potential and allocate their daily spare time for positive activities.

The implementation of a blended learning model brings a positive impact on problem-solving skills. This condition can be seen from the students' responses on each learning activity in the classroom (direct synchronous) to solve problems given by teachers or found by themselves. It is similar to the previous studies conducted by Dwiyogo (2018) and Tsai (2017), proving that students are accustomed to solve their problems in the learning process using the blended model, and it will positively affect the problem-solving skills of students. Problem-solving skills are really related to critical thinking skills. Some of the studies by Van Laar et al. (2017) and Eyisi (2016) showed that there is a positive correlation between problem-solving and critical thinking skills. Students who have good problem-solving skills tend to have critical thinking skills.

Technology as a learning media helps students to create a more effective and efficient learning environment. It is indicated by the ease of accessing information or knowledge using elearning media. Students can utilise facilities given by the lecturer to learn anywhere and anytime and either collaboratively (online discussion) or independently (Jou, Lin \& Wu, 2016; Tamrin \& Basri, 2020). This condition prosecutes students to be accustomed to facing some learning problems, as they should be able to explore the learning technology or learning tools used in the learning process.

In e-learning, a lecturer, as the facilitator, has to provide facilities to students, including ebook, voice notes, and tutorial videos, as supplementary materials for studying at home or self-study. Besides that, a lecturer in the problem-based learning model who acts as the guide on the side because he/she becomes guidance in each learning activity in the classroom either in discussion and individual learning in the classroom or e-learning so that students can actively participate in the 
discussion and questions and answer sessions in the classroom. The benefit of this activity is that students can find solutions to the problems they face and synthesise the knowledge they obtain from inside and outside the classroom so that they can come up with new ideas to solve each task given by teachers.

Besides that, the blended learning model helps students to develop their reasoning skills. The integration between synchronous learning and e-learning motivates students to develop their logical reasoning skills (Regina, Roy \& Alotebi, 2015; Lestari et al., 2019). Changwong, Sukkamart and Sisan (2018) and Siburian, Corebima and Saptasari (2019) consider that logical reasoning skill is part of critical thinking skill. Therefore, to increase the critical thinking skills of students, it can be done by focusing on the increase in logical reasoning skills of students. However, the involvement of technology during the learning process does not always correlate with the development of one's reasoning. This condition can be experienced by a lecturer who is unable to take advantage of the positive potential of technology and ignore the classroom environment. Therefore, the collaboration between lecturers and students with a good understanding of their role in blended learning is important to create a conducive learning environment (Wahyuni et al., 2019).

The blended learning model does not only positively affect the critical thinking skill of students, but also positively affects the communication skill of students. One of the main focuses of the blended learning model is a student-centred learning system that requires a student to actively involve in each group or individual learning activity. It helps students to grow in confidence, to motivate themselves to deliver their ideas and to respect and appreciate their friends' opinions in the classroom. Besides that, online communication can facilitate them to share knowledge. Students can share knowledge using the discussion feature and personally communicate using messenger apps with their friends. It allows students to spend their time developing their potential, and a blended learning model accommodates the growth of students' high thinking order skills that is important for scientific communication through scientific writing. The benefit of blended learning for communication skills is also shown by Banditvilai (2016), wherein online learning is beneficial in improving students' language skills. Furthermore, he stated that online learning improves students' curiosity and motivation to learn in the classroom. The advantage of the blended learning model for students' communication skills is supported by Suwono and Dewi (2019), who states that the implementation of problem-based learning online can improve students' competence.

Student-centred learning can be conducted anytime and anywhere and accommodates students with a better or more positive learning style. The blended learning model with the adoption of this concept effectively supports students to independently involve more in the learning activities outside the classroom. The flexibility of information gathered by students enables them to identify, to analyse and to evaluate the information they need, and to use them for their skill development in the classroom or their future. This condition obviously can improve students' communication skills because the method has the flexibility that can minimise the gap between students and teachers as instructors and assist students to communicate more effectively with their peers (Sriarunrasmee, Techataweewan \& Mebusaya, 2015).

\section{Conclusion}

Based on the data presentation and analysis, it can be concluded that the blended learning model is effective to increase students' critical thinking and communication skills. Furthermore, the improvement of these skills in the experimental group was more significant than in the control group taught with traditional learning. This condition is influenced by the positive aspects of the blended learning model, which in this case requires students to actively involve in the learning activities in both 
the classroom (offline) and outside the classroom (online). However, to maximise the output of the learning, all elements of educational institutions, including the management, trainers, educational staff, and students, need to collaboratively implement the blended learning system.

It is suggested to lecturers to apply the blended learning model to assist them to carry out their roles as facilitators and motivators in the classroom so that students can be supported to develop the competence and talent they have. In addition, through the implementation of the online blended problem-based learning model using LMS Edmodo that is one of learning social platforms, students are expected to be more motivated and more independent while studying. As a consequence, they can develop their knowledge and competence to be more competitive and professional in the 4.0 revolution era. Future researchers are expected to widen the implementation of the blended learning model not only in the employability aspects related to critical thinking and communication skills but also in other competencies based on the discipline on which they focus

\section{References}

Banditvilai, C. (2016). Enhancing students' language skills through blended learning. Electronic Journal of eLearning, 14(3), 10.

Blau, I., Shamir-Inbal, T., \& Avdiel, O. (2020). How does the pedagogical design of a technology-enhanced collaborative academic course promote digital literacies, self-regulation, and perceived learning of students?. The internet and higher education, 45, 100722.

Cahyani, N. I., \& Azizah, U. (2019). Penerapan Model Pembelajaran Inkuiri Terbimbing Untuk Melatihkan Keterampilan Berpikir Kritis Siswa Pada Materi Laju Reaksi Kelas XI SMA. Unesa Journal of Chemical Education, 8(3).

Changwong, K., Sukkamart, A. \& Sisan, B. (2018). Critical thinking skill development: analysis of a new learning management model for Thai high schools. Journal of International Studies, 11(2).

Demir, M. K. (2006). Candidate teachers' learning styles and teaching social science, ${ }^{*}$ Sınıf öğretmeni adaylarının öğrenme stilleri ve sosyal bilgiler öğretimi+. Eurasian Journal of Educational Research (EJER), 23, 28-37

Dilekli, Y. (2017). The relationships between critical thinking skills and learning styles of gifted students. European Journal of Education Studies, 3(4), 69-96.

Dwiyogo, W. D. (2018a). Developing a blended learning-based method for problem-solving in capability learning. The Turkish Online Journal of Educational Technology, 17(1), 11.

Dwiyogo, W. D. (2018b). Pembelajaran berbasis blended learning (1st ed.). Depok, Indonesia: RajaGrafindo Persada.

Eyisi, D. (2016). The usefulness of qualitative and quantitative approaches and methods in researching problemsolving ability in science education curriculum. Journal of Education and Practice, 7(15), 91-100.

Erdogan, F. (2020). The relationship between prospective middle school mathematics teachers' critical thinking skills and reflective thinking skills. Participatory Educational Research, 7(1), 220-241.

Hart, J. L. (2019). Interdisciplinary project-based learning as a means of developing employability skills in undergraduate science degree programs. Journal of Teaching and Learning for Graduate Employability, 10(2), 50-66.

Hunaepi, H., Firdaus, L., Samsuri, T., Susantini, E., \& Raharjo, R. (2020). Implementasi Worksheet Inkuiri Terintegrasi Kearifan Lokal Untuk Meningkatkan Keterampilan Berpikir Kritis Mahasiswa. Bioscientist: Jurnal Ilmiah Biologi, 8(1), 158-169. 
Jou, M., Lin, Y. T. \& Wu, D. W. (2016). Effect of a blended learning environment on student critical thinking and knowledge transformation. Interactive Learning Environments, 24(6), 1131-1147. doi:10.1080/10494820.2014.961485

Kavenuke, P. S., Kinyota, M. \& Kayombo, J. J. (2020). The critical thinking skills of prospective teachers: Investigating their systematicity, self-confidence and scepticism. Thinking Skills and Creativity, 37, 100677.

Kyaw, B. M., Posadzki, P., Paddock, S., Car, J., Campbell, J., \& Car, L. T. (2019). Effectiveness of digital education on communication skills among medical students: systematic review and meta-analysis by the digital health education collaboration. Journal of medical Internet research, 21(8), e12967.

Lane, S. (2016). Developing employability skills by using blended learning. American Journal of Educational Research, 4, 47-53.

Lestari, H., Usman, M., \& Hasmawati, H. (2019). Kemampuan Berpikir Logis dan Penguasaan Kosa kata Bahasa Jerman. Eralingua: Jurnal Pendidikan Bahasa Asing dan Sastra, 3(2).

Regina, G.-G., Roy, M. \& Alotebi, H. (2015). The interplay of technology and critical thinking skills in the 21st century blended classroom. International Journal of Advanced Research in Education Technology (IJARET), 2(3), 4.

Ristanto, R. H., Djamahar, R., Heryanti, E., \& Ichsan, I. Z. (2020). Enhancing Students' Biology-Critical Thinking Skill through CIRC-Based Scientific Approach (Cirsa). Universal Journal of Educational Research, 8(4A), 1-8.

Rubin, R. B., Palmgreen, P. \& Sypher, H. E. (2020). Communicative competence scale. In Communication research measures (pp. 125-129). Abingdon, UK: Routledge.

Sadri, I., Fithriani, R., Salmiah, M., \& Hamidah, S. (2019). Suggesting Critical-Thinking and Problem-Solving Method into Teaching English Reading to EFL Students in Indonesia. KnE Social Sciences, 294-304.

Sagala, Y. D. A., Simajuntak, M. P., \& Bukit, N. (2019, December). Implementation of Project-Based Learning (PjBL) in Collaboration Skills and Communication Skills of Students. In 4th Annual International Seminar on Transformative Education and Educational Leadership (AISTEEL 2019). Atlantis Press.

Siburian, J., Corebima, A. D. \& Saptasari, M. (2019). The correlation between critical and creative thinking skills on cognitive learning results. Eurasian Journal of Educational Research, 19(81), 99-114.

Smith, L., Gillette, C., Taylor, S. R., Manolakis, M., Dinkins, M., \& Ramey, C. (2019). A semester-long critical thinking course in the first semester of pharmacy school: Impact on critical thinking skills. Currents in Pharmacy Teaching and Learning, 11(5), 499-504.

Sriarunrasmee, J., Techataweewan, W. \& Mebusaya, R. P. (2015). Blended learning supporting self-directed learning and communication skills of Srinakharinwirot University's first year students. Procedia-Social and Behavioral Sciences, 197, 1564-1569. doi:10.1016/j.sbspro.2015.07.111

Suwono, H. \& Dewi, E. K. (2019). Problem-based learning blended with online interaction to improve motivation, scientific communication and higher order thinking skills of high school students. 030003. doi:10.1063/1.5094001

Tamrin, A. F., \& Basri, B. (2020). Edmodo-Based Learning and the Students' Perception. Eralingua: Jurnal Pendidikan Bahasa Asing dan Sastra, 4(1), 64-72.

Topluer, A.(2008). The relationship between organizational conflict and communication competency levels of primary school administrators (Unpublished Master Thesis). Inonu Universitesi, Malatya.

Tsai, M.-H. \& Tang, Y.-C. (2017). Learning attitudes and problem-solving attitudes for blended problem-based learning. Library Hi Tech, 35(4), 615-628. doi:10.1108/LHT-06-2017-0102 
Ustüner, M. \& Kis, A. (2014). The relationship between communication competence and organizational conflict: a study on heads of educational supervisors. Eurasian Journal of Educational Research, 56, 23-44.

Van Laar, E., Van Deursen, A. J., Van Dijk, J. A. \& De Haan, J. (2017). The relation between 21st-century skills and digital skills: a systematic literature review. Computers in Human Behavior, 72, 577-588.

Wahyuni, S., Sanjaya, I. G. M., Erman, E., \& Jatmiko, B. (2019). Edmodo-Based Blended Learning Model as an Alternative of Science Learning to Motivate and Improve Junior High School Students' Scientific Critical Thinking Skills. International Journal of Emerging Technologies in Learning (iJET), 14(07), 98-110.

Yu, W. -C. W., Lin C.C., Ho M-H, Wang J. (2015). Technology facilitated PBL pedagogy and its impact on nursing students academic achievement and critical thinking dispositions. The Turkish Online Journal of Educational Technology, 14(1), 97-107. 